Food, Dairy and Home Economic Research

http:/www.journals.zu.edu.eg/journalDisplay.aspx?.Journalld=1\&queryType=Master

\title{
EFFECT OF SOME NATURAL ANTIOXIDANTS ON OXIDATIVE STABILITY OF GHEE LIKE PRODUCT CONTAINING HIGH LEVELS OF POLYUNSATURATED FATTY ACIDS
}

\author{
Eslam E.E. Diab", S.A. Khalifa, E.H. Atwaa and A.A Abd-Elbaky \\ Food Sci. Dept., Fac. Agric., Zagazig Univ., Egypt
}

\section{Received: 05/03/2018 ; Accepted: 15/04/2018}

\begin{abstract}
This study was carried out to estimate the antioxidant activity and phenolic compounds of moringa and mulberry leaves extracts and evaluate the effect of addition of these natural extracts on oxidative stability of ghee like product containing high level of polyunsaturated fatty acids. Ethanolic extracts of moringa or mulberry leaves were added to ghee at concentrations of 200, 400 and $600 \mathrm{ppm}$. Also, butylated hydroxyl anisole (BHA) was added to a sample at a concentration of $200 \mathrm{ppm}$ and other sample was prepared without any additives serving as control. All samples were incubated at $63 \pm 1{ }^{\circ} \mathrm{C} / 21$ days to accelerate the fat autooxidation. Samples were analyzed when fresh and weekly until the end of the incubation period (21 days) for peroxide, acid values, thiobarbituric acid (TBA) test and Rancimat test. Results showed that these extracts have a high content of phenolic compounds, and gave high antioxidant activity. The ethanolic extracts at rates of 400 and $600 \mathrm{ppm}$ of both extracts were more effective in preventing the development of the peroxide and acid values and TBA test in ghee like product samples compared to BHA and control ghee like product.Moringa extract was found to be more effective. Ethanolic extracts at rates of 400 and $600 \mathrm{ppm}$ of two extracts showed the higher induction period as compared to BHA and control ghee like product counter parts in the rancimat. The results recommended that ethanolic extracts under study, at a concentration of $400 \mathrm{ppm}$, could be used to retard fat autooxidation in ghee like product containing increased level of polyunsaturated fatty acids.
\end{abstract}

Key words: Ghee, mulberry leaves, moringa leaves, polyunsaturated fatty acids, autooxidation.

\section{INTRODUCTION}

Consumer demands in the field of food production have changed considerably. Consumers are becoming aware that food contributes directly to their health (Mollet and Rowland, 2002). Today food is not intended to only satisfy hunger and to provide necessary nutrients for human but also to prevent nutritionrelated disease and improve physical and mental well-being of consumers (Menrad, 2003).

Milk fat has been considered to be hypercholesterolemic because it contains cholesterol and a generous proportion of saturated long chain fatty acids (Ney, 1991). Dietary fat has been shown to be linked with increased risk of obesity, atherosclerosis, cardiovascular disease, hypertension and injury disease associated with lipid oxidation (Fenlon and Guinee, 2000; Mensink et al., 2003; Rodrigues and Gioielli, 2003).

Efforts have been directed to formulate food with ingredients that help to lower health risk (Liong and Shal, 2006). Particular attention has focused on the health benefits of reducing saturated fat by increasing mono and polyunsaturated fatty acids in food products. Consequently attempts have been made to use vegetable oils in food formulation as their use may offer health and dietary advantages commonly associated with their mono and polyunsaturated fatty acids content (Mensink,

\footnotetext{
Corresponding author: Tel. : +201027889667

E-mail address: eng.eslam.diab@gmail.com
} 
2005; Shehata, 2005; Williams, 2006; Zaghlool et al., 2009; Ramadan, 2014) However, increasing the level of unsaturated fatty acids in food products was found to be complicated with their high sensitivity to autooxidation and the development of oxidative rancidity (During $\boldsymbol{e t}$ al., 2000a,b; Ibrahim, 2003).

Antioxidants has been broadly described as all substance that inhibit oxidation reaction regardless of the mechanism and narrowly as those compounds that interrupt the free radical chain reaction involved in food oxidation and those scavenging singlet oxygen (Hamid $\boldsymbol{e t}$ al., 2010).

Food antioxidants may be synthetic or natural. The toxicological effect of synthetic antioxidants together with consumer preference for natural products have resulted in an increased interest to use alternative natural and safe sources of food antioxidants. Considerable interest have been given recently to extract natural antioxidants present in numerous plant materials (ElShourbagy and El-Zahar, 2014; Zaki et al., 2014; Atwaa et al., 2015; El-Hadary et al., 2015). In addition, research has indicated that natural phenolic compounds can be extracted from raw materials or waste products of food industry (Peschel et al., 2006).

Moringa plant, found in tropical and subtropical countries, provides a rich and rare combination of zeatin, quercetin, kaempferom and many other phytochemicals. It is very important for its medicinal value. Various parts of the plant such as the leaves, roots, seeds, barks, fruits, flowers and immature pods act as cardiac and circulatory stimulants, possess antitumour, antipyretic, antiepileptic, antiinflammatory, antiulcer and antioxidants (Verma et al., 2012).

The leaves of mulberry tree are considered as the food of silkworms and have been commonly used as a food, food additive and in folklore medicine. There are 15 kinds of mulberry, which are widely distributed allover the country. The leaves and root bark of the mulberry tree are known worldwide as sources of phytotherapeutics, which have traditionally been used for the treatment of conditions related to type II diabetes. A large number of in vivo animal and human studies support the fact that the leaves and roots of mulberry tree have been commonly used as a traditional Chinese medicine for their hypolipidemic, antihypoglycemic, antioxidant, antihypertensive, anti-inflammatory, antiatherosclerotic, antitumor, anticonvulsant and vasodilator effects. Phytochemical studies showed that mulberry leaves are rich in a variety of constituents, including flavonoids, alkaloids, polysaccharides, amino acids, nucleosides, fatty acids, organic acid and microelements (Yang $\boldsymbol{e t}$ al., 2010; Jeszka-Skowron et al., 2014; Zhang et al., 2014; Tao et al., 2016).

Ghee (a heat clarified butter fat) is considered to be the richest fat dairy product commonly occupied a unique position among edible fats because of its pleasing, caramelized taste and granular texture .Taking into consideration, the growing consumer awareness to have certain nutrient components in food product which would benefit and protect against dietary risk. The present work was carried out to produce ghee like product with increased level of polyunsaturated fatty acids using an accepted blend of ghee and sunflower oil. Improving the oxidative stability of the product by natural antioxidant extracts represents the main aim of this work.

\section{MATERIALS AND METHODS}

\section{Materials}

Plant materials commonly found in Egypt, were used in this investigation. Moringa leaves (MOL), Mulberry leaves (MUL) were obtained from local market (Zagazig, Egypt), washed with distilled water and dried in an air draft drying oven $\left(40^{\circ} \mathrm{C}\right)$, and then ground and sieved through 60 mesh sieve and finally cooled or kept at $4^{\circ} \mathrm{C}$ until the extractions were carried out. Butylated hydroxy anisole (BHA), 1, 1diphenyl-2-picrylhydrazyl (DPPH), gallic acid and quercin were purchased from Sigma (St. Louis, MO, USA). All other chemicals and reagents were of the highest purity available. Raw Sunflower oil was obtained from Arma Company $10^{\text {th }}$ of Ramadan City. Egypt. 


\section{Methods}

\section{Chemical composition of plant materials}

The major chemical constituent, moisture, ash, crude fat, crude fiber, and crude protein were determined in triplicate according to AOAC (2007). Carbohydrate content was calculated by difference.

\section{Preparation of extracts}

Dried materials were extracted with ethanol $(70 \%)$, at a ratio of $1: 10(\mathrm{~W} / \mathrm{V})$ in closed vessels by stirring at room temperature $\left(25^{\circ} \mathrm{C}\right)$ for $4 \mathrm{hr}$., followed by filtration through filter paper Whatmann No 1 . The residues were reextracted again under the same conditions. All vessels were wrapped with aluminum foil to prevent light degradation during extraction (Yu et al., 2005). Ethanol extracts were evaporated in a rotary evaporator (Buchi-water bath-B-480, Switzerland) at $40{ }^{\circ} \mathrm{C}$, and freeze-dried (Thermo Electron Corporation- Heto Power Dry LL 300 Freeze Dryer, Czechoslovak). The dried extracts were weighed to determine the yield and stored at $-20^{\circ} \mathrm{C}$ until used.

\section{Radical scavenging activity (RSA) of extracts}

Radical scavenging activity (RSA) of extracts was measured by bleaching of the purple coloured solution of DPPH according to the method of Hanato et al. (1988). One hundred $\mu \mathrm{l}$ of each extract $(10 \mathrm{mg}$ extract $/ 10 \mathrm{ml}$ solvent) were added to $3 \mathrm{ml}$ of $0.1 \mathrm{mM} \mathrm{1,1-}$ diphenyl-2-picrylhydrazyl (DPPH) dissolved in ethanol. After incubation period of $60 \mathrm{~min}$ at room temperature, the absorbance was determined against a control at $517 \mathrm{~nm}$ (Gulcin et al., 2004). Percentage of antioxidant activity of DPPH was calculated as follows:

DPPH scavenging effect $(\%)=\left[\left(\mathrm{A}_{0}-\mathrm{A}_{1}\right) / \mathrm{A}_{0}\right] \times 100$

Where, $A_{0}$ is the absorbance of the control reaction and $A_{1}$ is the absorbance in the extract. Samples were analyzed in triplicate.

\section{Determination of total phenolic compounds (TPC)}

The concentration of TPC in all extracts was measured using UV spectrophotometer (JenwayUV-VIS spectrophotometer), based on a colorimetric oxidation/reduction reaction, as described by Škerget $\boldsymbol{e t}$ al. (2005) using Folin-
Ciocalteu reagent. Specifically, $0.5 \mathrm{ml}$ of diluted extract (10 mg in $10 \mathrm{ml}$ solvent) was mixed with $2.5 \mathrm{ml}$ of Folin-Ciocalteu reagent (diluted 10 times with distilled water) and $2 \mathrm{ml}$ of $\mathrm{Na}_{2} \mathrm{CO}_{3}$ $(75 \mathrm{~g} / 1 \mathrm{~L})$. The sample was incubated for $5 \mathrm{~min}$ at $50^{\circ} \mathrm{C}$ then cooled. For a control sample, 0.5 $\mathrm{ml}$ of distilled water was added. The absorbance was measured at $760 \mathrm{~nm}$. Total phenolic content expressed as gallic acid equivalent (GAE) was calculated, and the results were expressed as an mg GAE g ${ }^{-1}$ extract.

\section{Identification of phenolic acids using HPLC}

Phenolic acids of the dried extracts were identified according to the method described by Mattila et al. (2000). HPLC (Hewllet Packard series 1050, USA) equipped with auto sampling, injector, solvent degasser, UV detector set at $330 \mathrm{~nm}$ and quarter HP pump (series 1050) was used. Column (C18 hypersil BDS) with particle size $5 \mu \mathrm{m}$ was used. The separation was carried out with methanol and acetonitrile as a mobile phase at flow rate of $1 \mathrm{ml} / \mathrm{min}$. The column temperature was performed at room temperature $\left(25^{\circ} \mathrm{C}\right)$ throughout the experiment. Identification and quantification were carried out based on calibrations of the standards prepared from phenolic acids dissolved in a mobile phase. Retention time and peak area were used for calculation of phenolic acid compounds by the data analysis of Hewllet Packared Software.

\section{Preparation of ghee}

Ghee (a heat clarified butter fat) was prepared by boiling butter according to the method described by Dahram (2002). The butter used for preparing ghee was made from pasteurized unripened buffaloes milk cream. The main steps for preparing ghee were followed by the method described by (Reddy et al., 2016).

\section{Ghee like product preparation}

Ghee like product with increased level of polyunsaturated fatty acids was prepared from a blend of ghee (molted at $40-45^{\circ} \mathrm{C}$ ) and sunflower oil at a ratio of 60 and 40, respectively. The selected blending ratio was chosen on the basis of a preliminary trial which indicated that then chosen blending ratio gave a blend with acceptable flavours, texture and appearance as compared with pure ghee as shown in Table 1. 
Diab, et al.

Table 1. The properties of ghee/sunflower oil blend at a different ratios

\begin{tabular}{cccccc}
\hline \multicolumn{2}{c}{ Blend contents } & & \multicolumn{3}{c}{ Properties } \\
\cline { 5 - 6 } \cline { 5 - 6 } Ghee & Sunflower oil & Flavour & Texture & Appearance \\
\hline 100 & 0 & ++ & ++ & ++ \\
90 & 10 & ++ & ++ & ++ \\
80 & 20 & ++ & ++ & ++ \\
70 & 30 & + & ++ & ++ \\
60 & 40 & + & ++ & ++ \\
50 & 50 & \pm & + & + \\
40 & 60 & \pm & \pm & - \\
30 & 70 & - & - & - \\
20 & 80 & - & - & - \\
10 & 90 & - & - & + \\
\hline
\end{tabular}

++good, + accept, \pm fair, - unaccept

\section{Determination of fatty acid composition of the product using GC}

The fatty acid methyl esters were analyzed using to Thermo Ultra Trace GC series gas chromatography and Thermo DSQ $\|$ mass spectrometer from Thermo Fisher Scientific (Waltham, MA, USA). SGE BP x 70 column 25 $\mathrm{m} \times 0.25 \mathrm{~mm}, 0.25 \mu \mathrm{m}$ film thicknesses $(65 \%$ methyl-35\%- phenyl silicone) was used (Tong et al., 2007). Area under each fatty acid peak relative to the total area of all fatty acid peaks was used to quantify the fatty acids identified. Results are reported as $\mathrm{g}$ fatty acid/100 $\mathrm{g}$ of total fatty acids (Lutterodt et al., 2011).

\section{Degree of unsaturation}

Iodine value was determined as an index for the degree of unsaturation according to AOAC (2007).

\section{Oxidative stability testes}

Peroxide and acid values of ghee were determined according to AOAC (2007). While Thiobarbiuturic test (TBA) value of ghee was determined according to Keeny (1971).

\section{Accelerated stability test (Rancimat)}

The resistance to autooxidation was measured using Rancimat apparatus 743
(Metrohm, Herisau, Switzerland) instrument at $120^{\circ} \mathrm{C}$ with airflow rate of $20 \mathrm{l} / \mathrm{hr}$. The oxidative stability was expressed as induction period (hr.) or oxidative stability index (hr.). A $3.0 \mathrm{~g}$ sample of completely melted weighed accurately into each of the reaction vessels. The vessels were then placed in the heating block of the Rancimat apparatus. The reaction vessels were then connected to the measuring vessels via connecting tube. $60 \mathrm{ml}$ of deionized water was measured into each of the measuring vessels, containing the electrodes. The measuring vessels were also placed in the Rancimat apparatus. All parts were connected to the apparatus as per the operating instructions, and the test was carried out until the endpoints of all samples were reached, with a maximum allowable limit of 48 hours according to AOCS (1997).

\section{Statistical Analysis}

All data were statistically analyzed using the general linear models procedure of the statistical analysis system SAS (1998). Significances of differences were defined at $\mathrm{P}<0.05$. All experiments as well as related analysis results were repeated three times and all obtained data are expressed as an average. 


\section{RESULTS AND DISCUSSION}

\section{Chemical Composition of Dried Plant Materials}

The proximate composition of dried moringa, and mulberry leaves powder are illustrated in Table 2. The results showed that there were significant differences between the two samples for each content. Moisture, protein, fat, ash, and carbohydrate contents of moringa leaves powder were $(3.10,10.60,10.30,7.14$ and $68,86 \mathrm{~g} / 100 \mathrm{~g})$ respectively. These results are in agreement with the data obtained by Amabye (2016). While moisture, protein, fat, ash and carbohydrate contents of mulberry leaves powder were $(11.20, \quad 18.60, \quad 5.10, \quad 11.30 \quad 53,80 \quad \mathrm{~g} / 100 \mathrm{~g})$ respectively. These results are in agreement with the data obtained by Al-Kirshi et al. (2013).

\section{Yield of Extracts}

The yield of extracts is shown in Table 3 . Ethanolic moringa leaves extract had higher yield $(11.64 \mathrm{~g} / 100 \mathrm{~g})$, followed by ethanolic mulberry leaves extract $(9.68 \mathrm{~g} / 100 \mathrm{~g})$. These results agree with that reported by Memon et al. (2010), Sharma and Paliwal (2013) and Engsuwan et al. (2017). The variation in the extraction yield may be attributed to the content of total phenol compounds and the polarity of compounds in plants. Such differences have been reported by Prakasha et al. (2001).

\section{Total Phenolic Compounds}

Results presented in Table 3 show that ethanolic moringa leaves extract had the highest percentage of total phenols $(2932.24 \mathrm{mg} / 100 \mathrm{~g})$, followed by ethanolic mulberry leaves extract $(2612.42 \mathrm{mg} / 100 \mathrm{~g})$. These results agree with that reported by Memon et al. (2010) and Charoensin (2014). Therefore, ethanolic moringa and mulberry leaves extract could be a good source of bioactive compounds which have high antioxidative properties.

\section{Radical Scavenging Activity (RSA) of Plants Ethanolic Extracts}

The principal of this assay is billed on the measurement of the scavenging activity of the extract toward the stable radical DDPH. The free radicals DDPH is reduced to the corresponding hydrazine when it reacts with hydrogen donor the stability is evaluated by decolorizing assay which evaluate the decrease in the absorbance at $517 \mathrm{~nm}$ produces by the addition of the extract to DDPH solution. The degree of discoloration indicate the scavenging potential of the antioxidants compounds extract in term of hydrogen donating ability (Kriengsak et al., 2006). The results of radical scavenging activity (RSA) with DDPH for moringa and mulberry leaves extract are shown in Table 4. RSA for moringa leaves extract was found to be higher than that of mulberry leaves extract. RSA for moringa leaves extract was $89.72 \%$ while its was $88.40 \%$ for mulberry leaves extract. These values were comparable to that of BHA which was $91.32 \%$. The general trend of the obtained results is found to be in agreement with that reported by Charoensin (2014) for moringa and Memon et al. (2010) for mulberry leaves extract.

\section{Identification of Phenolic Compounds by HPLC}

Table 5 shows the phenolic compounds in both moringa and mulberry leaves extract. The phenolic compounds of moringa leaves extract ranged from 0.74 to $620.18 \mathrm{mg} / 100 \mathrm{~g}$. The predominant compound in moringa extract was rutin $620.18 \mathrm{mg} / 100 \mathrm{~g}$. These results are similar to those reported by Engsuwan et al. (2017). With respect to the phenolic compound identified in mulberry extract, their concentration ranged from 12.62 to $142.26 \mathrm{mg} / 100 \mathrm{~g}$. The predominant compound was found to be chlorogenic acid $(142.62 \mathrm{mg} / 100 \mathrm{~g})$. These results agree with that of Memon et al. (2010).

\section{Degree of Unsaturation and Fatty Acid Content of Ghee Like Product}

From Table 6, it can be seen that butter oil had a lower iodine value (43.8) than sunflower oil (128.6). When added sunflower oil to ghee at a rate of $40 \%$ increased iodine value of blend to (78.2). This mean that blended of ghee with $40 \%$ sunflower oil increased a level of unsaturated fatty acids to resultant blend.

\section{Fatty Acid Composition}

In general polyunsaturated fatty acids (PUFA) of the n- 6 family of which linoleic acid is the most important in the diet result in lowering of plasma cholesterol whereas those of n-3 family 
Diab, et al.

Table 2. Proximate chemical composition of moringa and mulberry leave's powder (g /100g)

\begin{tabular}{lcc}
\hline Item & Moringa leave's powder & Mulberry leave's powder \\
\hline Moisture & 3.10 & 11.20 \\
Protein & 10.60 & 18.60 \\
Fat & 10.30 & 5.10 \\
Ash & 7.14 & 11.30 \\
Carbohydrate & 68.86 & 53.80 \\
\hline
\end{tabular}

Table 3. The yield and total phenolic compounds of moringa and mulberry leaves extract

\begin{tabular}{lcc}
\hline Material & Yield (g/100g) & Total phenolic compounds (mg/100g) \\
\hline Moringa leaves & 11.64 & 2932.24 \\
Mulberry leaves & 9.68 & 2612.42 \\
\hline
\end{tabular}

Table 4. Scavenging effect of ethanolic moringa and mulberry leaves extract on DPPH radical scavenging as measured by changes at $515 \mathrm{~nm}$

\begin{tabular}{lccc}
\hline Radical scavenging & \multicolumn{3}{c}{ Materials } \\
\cline { 2 - 4 } activity (RSA) (\%) & Moringa leaves extract (\%) & Mulberry leaves extract (\%) & BHA (\%) \\
\cline { 2 - 4 } & 89.72 & 88.40 & 91.32 \\
\hline
\end{tabular}

Table 5. Identification of phenolic compounds in ethanol extracts of various materials as determined by HPLC

\begin{tabular}{lcc}
\hline Item & $\begin{array}{c}\text { Moringa leaves extract } \\
(\mathbf{m g} / \mathbf{1 0 0} \mathbf{g})\end{array}$ & $\begin{array}{c}\text { Mulberry leaves extract } \\
(\mathbf{m g} / \mathbf{1 0 0} \mathbf{g})\end{array}$ \\
\hline Gallic acid & 46.14 & $\mathrm{ND}$ \\
Syringic acid & 8.30 & 14.32 \\
Protocatechuic & $\mathrm{ND}$ & 14.20 \\
Chlorogenic & $\mathrm{ND}$ & 142.26 \\
Caffien & 0.74 & $\mathrm{ND}$ \\
Catechin & 6.14 & $\mathrm{ND}$ \\
Ferulic & 1.10 & 32.40 \\
Benzoic & 42.12 & 35.20 \\
Quercetin & 42.56 & $\mathrm{ND}$ \\
Rutin & 620.18 & $\mathrm{ND}$ \\
Coumaric acid & 1.90 & 12.62 \\
Vanillic acid & $\mathrm{ND}$ & 22.18 \\
Ellagic acid & 62.48 & $\mathrm{ND}$ \\
Tannic acid & 4.22 & $\mathrm{ND}$ \\
Total & 835.88 & 273.18 \\
\hline ND & &
\end{tabular}

ND = Not Detected 
Table 6. Iodine values of ghee and sunflower oil and its blends

\begin{tabular}{lc}
\hline Sample & Iodine value \\
\hline Ghee & 43.8 \\
Sunflower oil & 128.6 \\
Ghee/sunflower oil blend $(\mathbf{6 0 : 4 0} \mathbf{W} / \mathbf{W})$ & 78.2 \\
\hline
\end{tabular}

exemplified by $\alpha$ - lenolenic acid cause a lowering of plasma triacylglycerol but not of cholesterol (Gurr et al., 1989).

Fatty acid composition of ghee, sunflower oil and ghee+ sunflower is shown in Table 7. The results indicated that sunflower oil contained $17.82 \%$ total saturated fatty acids (SFA), while it contained $21.53 \%$ total mono unsaturated fatty acids (MUSFA) and $60.65 \%$ polyunsaturated fatty acids (PUSFA). These results are in agreement with the data obtained by Chugh and Dhawan (2014). Ghee contained $62.98 \%$ total saturated fatty acids (SFA), while it contained $32.40 \%$ total mono unsaturated fatty acids (MUSFA) and $5.80 \%$ polyunsaturated fatty acids (PUSFA). Blending of ghee and sunflower oil 60: 40 increased its contents from polyunsaturated fatty acids (PUSFA) from $5.80 \%$ to $29.44 \%$. Total saturated fatty acids in the blend were $46.34 \%$ compared with $62.98 \%$ in ghee. Reducing saturated fatty acids and increasing polyunsaturated fatty acids has dietary and healthy advantage. Increasing polyunsaturated fatty acids reduce blood cholesterol level and prevent coronary heart disease (Berger et al., 2015).

\section{Oxidative Stability of Ghee Like Product Containing High Levels of Unsaturated Fatty Acids}

\section{Peroxide value (PV)}

From the results presented in Table 8 , it could be seen that peroxide values were increased in all treatments during incubation at $63 \pm 1^{\circ} \mathrm{C}$ for 21 days. The changes in peroxide values take place in ghee/sunflower oil containing moringa or mulberry leaves extracts at a relatively lower rate compared with the blend without added ethanolic extracts. This observation was more remarkable with moringa leaves extract compared with mulberry leaves extract. Meanwhile the higher concentration (400 and $600 \mathrm{ppm}$ ) of the added extracts either in case of moringa or mulberry was more effective in reducing the development of peroxide value. In addition the antioxidant efficiency of moringa or mulberry leaves extracts was comparable to the effect of BHA (synthetic antioxidant). These results agree with Pawar et al. (2014) and Atwaa et al. (2015). The results obtained reveal that the effect of these additives as natural antioxidants, in retarding of fat-autooxidation in ghee like product is in the order moringa and mulberry leaves extracts (400 ppm). These results agree with Memon et al. (2010) and Engsuwan et al. (2017).

\section{Thiobarbiuturic (TBA) test}

It is well known that TBA values are taken as an index to evaluate the advance of oxidation changes occurred in oils and fats. The addition of moringa and mulberry leaves extract to ghee like product retarded the oxidative changes during accelerated storage at $63 \pm 1^{\circ} \mathrm{C}$ (Table 9). TBA values of ghee like product treated with both moringa and mulberry extracts were lower than that of ghee without additives and also they were comparable to those of ghee like product treated with BHA .Studying these results, it could be noticed that control ghee samples showed higher TBA values throughout the accelerated incubation period. The ethanolic moringa leaves extract treated ghee like product samples at different concentrations showed lower TBA values compared with ethanolic mulberry leaves extract, throughout the accelerated incubation period. There were significant differences $(\mathrm{p}<0.05)$ between treatments throughout the incubation period. These results agree with Asha et al. (2015) and Atwaa et al. (2015). 
Table 7. Fatty acid composition of ghee, sunflower oil and blend of ghee and sunflower oil (60:40 W/W)

\begin{tabular}{lcccc}
\hline Fatty acid & Ghee & $\begin{array}{c}\text { Sunflower } \\
\text { oil }\end{array}$ & $\begin{array}{c}\text { Ghee+ Sunflower } \\
\text { oil } \mathbf{6 0}: \mathbf{4 0}(\boldsymbol{W} / \boldsymbol{W})\end{array}$ \\
\hline Saturated fatty acid & Butyric $\left(\mathbf{C}_{\mathbf{4}}\right)$ & 3.20 & 0.00 & 1.36 \\
& Caproic $\left(\mathbf{C}_{\mathbf{6}}\right)$ & 1.80 & 0.00 & 1.00 \\
& Caprylic $\left(\mathbf{C}_{\mathbf{8}}\right)$ & 1.40 & 0.00 & 0.80 \\
& Capric $\left(\mathbf{C}_{\mathbf{1 0}}\right)$ & 2.60 & 0.00 & 1.50 \\
& Lauric $\left(\mathbf{C}_{\mathbf{1 2}}\right)$ & 2.40 & 0.61 & 1.70 \\
& Myristic $\left(\mathbf{C}_{\mathbf{1 4}}\right)$ & 8.62 & 0.12 & 4.90 \\
& Palmitic $\left(\mathbf{C}_{\mathbf{1 6}}\right)$ & 29.70 & 8.12 & 22.50 \\
& Stearic $\left(\mathbf{C}_{\mathbf{1 8}}\right)$ & 13.26 & 7.54 & 12.44 \\
& Arachidic & 0.00 & 0.36 & 0.12 \\
& Behenic & 0.00 & 0.84 & 0.36 \\
Mono unsaturated fatty acid & Lignoceric & 0.00 & 0.23 & 0.10 \\
& Palmitoleic & 0.00 & 0.12 & 0.04 \\
& Oleic $\left(\mathbf{C}_{\mathbf{1 8}} \mathbf{:}_{\mathbf{1}}\right)$ & 32.4 & 21.19 & 23.32 \\
Poly unsaturated fatty acid & Gadoleic & 0.00 & 0.22 & 0.08 \\
& Linoleic $\left(\mathbf{C}_{\mathbf{1 8}} \mathbf{:}_{\mathbf{2}}\right)$ & 2.70 & 60.20 & 28.14 \\
& Linolenic $\left(\mathbf{C}_{\mathbf{1 8}} \mathbf{0}_{\mathbf{3}}\right)$ & 1.30 & 0.45 & 0.90 \\
Total saturated fatty acid & Archidonic $\left(\mathbf{C}_{\mathbf{2 0}}\right)$ & 1.80 & 0.00 & 0.40 \\
Total unsaturated fatty acid & & 62.98 & 17.82 & 46.34 \\
Total mono unsaturated fatty acid & & 38.02 & 82.18 & 52.88 \\
Total polyunsaturated fatty acid & & 32.40 & 21.53 & 23.44 \\
\hline
\end{tabular}

Table 8. Peroxide value of ghee like product containing high polyunsaturated fatty acids enriched with antioxidants during incubation at $63 \pm 1^{\circ} \mathrm{C}$ for 21 days $(\mathrm{meq} / \mathrm{Kg})$.

\begin{tabular}{lcccc}
\hline Sample & \multicolumn{4}{c}{ Storage period (day) } \\
\cline { 2 - 5 } & $\mathbf{0}$ & $\mathbf{7}$ & $\mathbf{1 4}$ & $\mathbf{2 1}$ \\
\hline C & $2.46 \pm 0.015^{\mathrm{a}}$ & $5.13 \pm 0.010^{\mathrm{a}}$ & $12.36 \pm 0.020^{\mathrm{a}}$ & $17.63 \pm 0.011^{\mathrm{a}}$ \\
C1 & $2.43 \pm 0.010^{\mathrm{a}}$ & $3.62 \pm 0.015^{\mathrm{c}}$ & $4.17 \pm 0.010^{\mathrm{de}}$ & $4.86 \pm 0.015^{\mathrm{d}}$ \\
T1 & $2.46 \pm 0.015^{\mathrm{a}}$ & $4.12 \pm 0.010^{\mathrm{b}}$ & $5.21 \pm 0.015^{\mathrm{cd}}$ & $6.31 \pm 0.015^{\mathrm{c}}$ \\
T2 & $2.45 \pm 0.015_{\mathrm{a}}$ & $3.36 \pm 0.020^{\mathrm{cd}}$ & $3.92 \pm 0.010^{\mathrm{e}}$ & $4.23 \pm 0.010^{\mathrm{e}}$ \\
T3 & $2.44 \pm 0.015^{\mathrm{a}}$ & $2.94 \pm 0.020^{\mathrm{e}}$ & $3.25 \pm 0.015^{\mathrm{f}}$ & $3.86 \pm 0.015^{\mathrm{f}}$ \\
T4 & $2.46 \pm 0.015^{\mathrm{a}}$ & $4.36 \pm 0.015^{\mathrm{ab}}$ & $5.76 \pm 0.015^{\mathrm{c}}$ & $6.94 \pm 0.010^{\mathrm{bc}}$ \\
T5 & $2.44 \pm 0.010^{\mathrm{a}}$ & $3.53 \pm 0.015^{\text {cd }}$ & $4.12 \pm 0.005^{\mathrm{de}}$ & $4.77 \pm 0.010^{\mathrm{de}}$ \\
T6 & $2.46 \pm 0.020^{\mathrm{a}}$ & $3.26 \pm 0.020^{\mathrm{d}}$ & $3.82 \pm 0.010^{\mathrm{e}}$ & $4.15 \pm 0.015^{\mathrm{e}}$ \\
LSD & 0.002 & 0.023 & 0.019 & 0.018 \\
\hline
\end{tabular}

Data are expressed as mean \pm standard deviation (SD). Values given represent means of three determinations

$\mathrm{C}$ : Control without antioxidants

$\mathrm{T}_{1}$ : Ghee treated with 200ppm moringa leaves extract.

$\mathrm{T}_{3}$ : Ghee treated with $600 \mathrm{ppm}$ moringa leaves extract.

$\mathrm{T}_{5}$ : Ghee treated with 400ppm mulberry leaves extract.
$\mathrm{C}_{1}$ : Ghee treated with 200ppm BHA (positive control)

$\mathrm{T}_{2}$ : Ghee treated with 400pp moringa leaves extract.

$\mathrm{T}_{4}$ : Ghee treated with $200 \mathrm{ppm}$ mulberry leaves extract.

$\mathrm{T}_{6}$ : Ghee treated with $600 \mathrm{ppm}$ mulberry leaves extract 
Table 9. The TBA value of ghee like product containing high polyunsaturated fatty acids enriched with antioxidants during incubation at $63 \pm 1^{\circ} \mathrm{C}$ for 21 days $(O . D$ at $532 \mathrm{~nm})$

\begin{tabular}{lcccc}
\hline Sample & \multicolumn{4}{c}{ Storage period (day) } \\
\cline { 2 - 5 } & $\mathbf{0}$ & $\mathbf{7}$ & $\mathbf{1 4}$ & $\mathbf{2 1}$ \\
\hline C & $0.072 \pm 0.0015^{\mathrm{a}}$ & $0.097 \pm 0.0021^{\mathrm{a}}$ & $0.181 \pm 0.0021^{\mathrm{a}}$ & $0.243 \pm 0.0020^{\mathrm{a}}$ \\
C1 & $0.074 \pm 0.0020^{\mathrm{a}}$ & $0.086 \pm 0.0015^{\mathrm{ab}}$ & $0.121 \pm 0.0015^{\mathrm{bc}}$ & $0.177 \pm 0.0061^{\mathrm{b}}$ \\
T1 & $0.076 \pm 0.0015^{\mathrm{a}}$ & $0.092 \pm 0.0021^{\mathrm{a}}$ & $0.137 \pm 0.0061^{\mathrm{b}}$ & $0.213 \pm 0.0153^{\mathrm{ab}}$ \\
T2 & $0.0733 \pm 0.0015^{\mathrm{a}}$ & $0.083 \pm 0.0015^{\mathrm{ab}}$ & $0.113 \pm 0.0153^{\mathrm{bc}}$ & $0.162 \pm 0.0015^{\mathrm{c}}$ \\
T3 & $0.0713 \pm 0.0015^{\mathrm{a}}$ & $0.074 \pm 0.0153^{\mathrm{b}}$ & $0.095 \pm 0.0015^{\mathrm{c}}$ & $0.120 \pm 0.0100^{\mathrm{d}}$ \\
T4 & $0.0767 \pm 0.0015^{\mathrm{a}}$ & $0.094 \pm 0.0015^{\mathrm{a}}$ & $0.157 \pm 0.0061^{\mathrm{ab}}$ & $0.220 \pm 0.0100^{\mathrm{ab}}$ \\
T5 & $0.0753 \pm 0.015^{\mathrm{a}}$ & $0.087 \pm 0.0015^{\mathrm{ab}}$ & $0.012 \pm 0.0015^{\mathrm{d}}$ & $0.177 \pm 0.0061^{\mathrm{b}}$ \\
T6 & $0.0733 \pm 0.0015^{\mathrm{a}}$ & $0.076 \pm 0.0153^{\mathrm{b}}$ & $0.097 \pm 0.0021^{\mathrm{c}}$ & $0.130 \pm 0.0100^{\mathrm{d}}$ \\
LSD & 0.002 & 0.011 & 0.009 & 0.012 \\
\hline
\end{tabular}

Data are expressed as mean \pm standard deviation (SD). Values given represent means of three determinations

\section{Acid Value}

Table 10 shows clearly that there are significant differences $(\mathrm{p}<0.05)$ between ghee like product treatments through the incubation period. Considerable increases of acid value were observed until the end of incubation period of ghee like product at $63 \pm 1^{\circ} \mathrm{C}$, for all samples including the control one.

Moringa and mulberry leaves extracts at rate of 400 and $600 \mathrm{ppm}$ showed the lower increase in acid value of ghee like product compared with synthetic antioxidants' referring to the high effect of moringa and mulberry leaves extracts in delaying ghee like product hydrolysis. Moringa leaves extract was more effective followed by the mulberry leaves extract comparing with the control. Moringa and mulberry leaves extract were favorable as an antioxidant agent (Memon et al., 2010; Engsuwan et al, 2017). These results agree with Asha et al. (2015) and Atwaa et al. (2015).

\section{Accelerated stability test (Rancimat)}

The effect of extracts (ethanolic) and BHA incorporation on oxidative stability of ghee like product containing high level of unsaturated fatty acids was evaluated by Rancimat equipment and the results are presented in Table 11. The induction time was used as indicator of antioxidative potential of antioxidants used. The induction period (IP) is also known as oxidative stability index (OSI) determined as the time required reaching an end point of oxidation corresponding to either a level of detectable rancidity or a fast change in the rate of oxidation (Presa and Lopez, 1995).

The ethanolic extracts were found to be more effective in stabilizing ghee like product against oxidative deterioration as compared to control ghee like product. However, ghee like product containing ethanolic extracts had significantly higher $(\mathrm{p}<0.05)$ induction periods than that of control sample. Nahak and Sahu (2010) reported that phenolic compounds are considered to be the most important antioxidative components of herb and other plant materials, and a good correlation exist between the concentrations of plant phenolic and the total antioxidant capacities. Ghee like product containing ethanolic extracts had significantly higher $(\mathrm{P}<0.05)$ antioxidative effectiveness followed by ghee like product enriched with BHA and finally control ghee like product. The antioxidant activity of extracts and BHA in ghee like product as measured by Rancimat, was in the following order: Moringa ethanolic extract $(600$ ppm) $>$ Mulberry ethanolic extract $(600 \mathrm{ppm})>$ Moringa ethanolic extract $(400 \mathrm{ppm})>$ Mulberry ethanolic extract $(400 \mathrm{ppm})>$ BHA > Moringa ethanolic extract $(200 \mathrm{ppm})>$ Mulberry ethanolic extract $(200 \mathrm{ppm})>$ control (Table 11). These results agree with the results obtained with Pawar et al. (2014) and ElShourbagy and El-Zahar (2014). 
Table 10. Acid value of ghee containing high polyunsaturated fatty acids enriched with antioxidants during incubation at $63 \pm 1^{\circ} \mathrm{C}$ for 21 days (mg KOH/g oil)

\begin{tabular}{lcccc}
\hline Sample & \multicolumn{4}{c}{ Storage period (day) } \\
\cline { 2 - 5 } & $\mathbf{0}$ & $\mathbf{7}$ & $\mathbf{1 4}$ & $\mathbf{2 1}$ \\
\hline C & $0.46 \pm 0.015^{\mathrm{a}}$ & $0.82 \pm 0.015^{\mathrm{a}}$ & $1.21 \pm 0.015^{\mathrm{a}}$ & $1.95 \pm 0.015^{\mathrm{a}}$ \\
C1 & $0.44 \pm 0.015^{\mathrm{a}}$ & $0.68 \pm 0.015^{\mathrm{b}}$ & $0.85 \pm 0.015^{\mathrm{c}}$ & $1.13 \pm 0.010^{\mathrm{c}}$ \\
T1 & $0.43 \pm 0.020^{\mathrm{a}}$ & $0.74 \pm 0.015^{\mathrm{ab}}$ & $0.92 \pm 0.015^{\mathrm{bc}}$ & $1.23 \pm 0.015^{\mathrm{bc}}$ \\
T2 & $0.47 \pm 0.020^{\mathrm{a}}$ & $0.60 \pm 0.026^{\mathrm{bc}}$ & $0.83 \pm 0.015^{\mathrm{cd}}$ & $1.04 \pm 0.010^{\mathrm{d}}$ \\
T3 & $0.43 \pm 0.010^{\mathrm{a}}$ & $0.54 \pm 0.020^{\mathrm{c}}$ & $0.76 \pm 0.015^{\mathrm{d}}$ & $0.92 \pm 0.015$ \\
T4 & $0.45 \pm 0.032^{\mathrm{a}}$ & $0.78 \pm 0.020^{\mathrm{ab}}$ & $0.97 \pm 0.020^{\mathrm{b}}$ & $1.33 \pm 0.015^{\mathrm{b}}$ \\
T5 & $0.44 \pm 0.020^{\mathrm{a}}$ & $0.64 \pm 0.015^{\mathrm{b}}$ & $0.88 \pm 0.010^{\mathrm{c}}$ & $1.06 \pm 0.015^{\mathrm{d}}$ \\
T6 & $0.46 \pm 0.015^{\mathrm{a}}$ & $0.58 \pm 0.015^{\mathrm{bc}}$ & $0.82 \pm 0.010^{\mathrm{cd}}$ & $1.02 \pm 0.015^{\mathrm{d}}$ \\
LSD & 0.028 & 0.026 & 0.021 & 0.019 \\
\hline
\end{tabular}

Data are expressed as mean \pm standard deviation (SD). Values given represent means of three determinations.

Table 11. Accelerated stability test (Rancimat) of ghee like product containing high levels of polyunsaturated fatty acids enriched with natural antioxidants

\begin{tabular}{lc}
\hline Sample & Induction period (hr.) \\
\hline C & $12.8 \pm 0.24^{\mathrm{f}}$ \\
C1 & $22.4 \pm 0.28^{\mathrm{bc}}$ \\
T1 & $18.6 \pm 0.18^{\mathrm{d}}$ \\
T2 & $23.4 \pm 0.22^{\mathrm{b}}$ \\
T3 & $25.8 \pm 0.25^{\mathrm{a}}$ \\
T4 & $16.2 \pm 0.21^{\mathrm{e}}$ \\
T5 & $21.6 \pm 0.18^{\mathrm{c}}$ \\
T6 & $24.7 \pm 0.15^{\mathrm{a}}$ \\
LSD & 0.018 \\
\hline
\end{tabular}

Data are expressed as mean \pm standard deviation (SD). Values given represent means of three determinations. 


\section{Conclusion}

Various extracts of moringa leaves extract and mulberry leaves extract showed varying degrees of antioxidant activity. It is notable that moringa leaves extract exhibited strong antioxidant capacity, followed by mulberry leaves extract. Therefore, these extracts could be used as preservative ingredients to improve oxidative stability of ghee like product containing high levels of polyunsaturated fatty acids.

\section{REFERENCES}

Al-Kirshi, R.A., A. Alimon, I. Zulkifli, S. Atefeh, M.W. Zahari and M. Ivan (2013). Nutrient digestibility of mulberry leaves (Morus Alba). Ital J. Anim Sci., 12 (36): 219221.

Amabye, T.G.(2016). Chemical compositions and nutritional value of Moringa oleifera available in the market of mekelle. J. Food and Nutr. Sci., 3 (5): 187-190.

AOAC (2007). Association of Official Analytical Chemists-Official Method of Analysis. (18 ${ }^{\text {th }}$ Ed.), Benjamin Franklin Station Washington, DC, USA.

AOCS (1997). Official Methods and Recommended Practices of American Oil Chemists' Society, $4^{\text {th }}$ Ed. AOCS, Champaign, IL.

Asha, A., M. Manjunatha, R.M. Rekha, B. Surendranath, P. Heartwin, J. Rao, E. Magdaline and C.H. Sinha (2015). Antioxidant activities of orange peel extract in (butter oil) stored at different storage temperatures. J. Food. Sci. Technol., 52 (12): 8220-8227.

Atwaa, S.H., M.Z. El-Abbassy and K.M. ElZahar (2015). Influence of some natural antioxidants on Samna stability. Zagazig J. Agric. Res., 41 (3) : 525-533.

Berger, S.G., R. Raman and P. Vislowerthan (2015). Dietary cholesterol and cardiovascular diseases A Systemic Rev. Ame. J. Clivinnutr, $102: 276$.

Charoensin, S. (2014). Antioxidant and anticancer activities of Moringa oleifera leaves. J. Med. Plant Res., 8 (7): 318-325.
Chugh, B. and K. Dhawan (2014). Storage studies on mustard oil blends. J. Food Sci. Technol., 51 (4): 762-767.

Dahram, P. (2002). Industrial Practices in Production and Preservation of Ghee. Adv. Fat Rich Prod. Nat. Dairy Res. Inst. Karnal, $132001: 121$.

During, A., N. Combe, S. Mazette and B. Entressangles (2000a). Effect on cholesterol in the rats of a soft ripened cheese containing vegetable oils, J. Ame. Cool. Nutr., 19 (4): 458-466.

During, A., S. Mazette, N. Combe and B. Entressangles (2000b). Lipolysis and oxidative stability a soft ripened cheese containing vegetable oils. J. Dairy Res., 76: 461-466.

El-Hadary, A.R.E., G.A. El-Shourbagy, A.M. Sulieman and S.E. El-Nemer (2015). Impact of some technological treatments on antioxidant capacity of banana and potato peel extracts. Zagazig J. Agric. Res., 42 (4): 813-824.

El-Shourbagy, G.A. and K.M. El-Zahar (2014). Oxidative stability of ghee as affected by natural antioxidants extracted from food processing wastes. Zagazig J. Agric. Res., 59 (2): 213-220.

Engsuwan, J., N. Waranuchb, N. Limpeanchobc, and K. Ingkaninana (2017). HPLC methods for quality control of Moringa oleifera extract using isothiocyanates and astragalin as bioactive markers. Sci. Asia, $43: 169-174$

Fenelon, M.A. and T.P. Guinee (2000). Falvour Development in Low Fat Cheese in Proc. $6^{\text {th }}$ Morrepark cheese symposim T.M. Cogen., Ed. Teagasc, Dublin, 31 -42.

Gulcin, I., O.I. Kufrevioglu, M. Oktay and M.E. Buyukokuroglu (2004). Antioxidant, antimicrobial, antiulcer and analgesic activities of nettle (Urtica dioica L.). J. Ethnopharmacol., 90: 205-215.

Hamid, A.A., O.O. Alyelaagb, L.A. Usman, O.M. Ameen and A. Lawal (2010). Antioxidants; Its medicinal and pharmacological Applications. Afr. J. Pure and Appl. Chem., 4 (8): 142-151. 
Hanato, T., H. Kagawa, T. Yasuhara and T. Okuda (1988). Two new flavonoids and other constituents in licorice root: Their relative astringency and radical scavenging effects. Chem. Pharm. Bull., 36: 2090-2097.

Ibrahim, H.M. (2003). Studies on Some Vegetables Oils. M.Sc. Thesis, Fac. Agric., Zagazig Univ., Egypt.

Jeszka-Skowron, M., E. Flaczyk, J. Jeszka, Z. Krejpcio, E. Król and M.S. Buchowski (2014). Mulberry leaf extract intake reduces hyperglycaemia streptozotocin (STZ)induced diabetic rats fed high-fat diet. J. Funct. Foods, 8: 9-17.

Keeny, P.G. (1971). A guide to controlling oxidation in butter creams-candy and snack industry, $136(7): 68$.

Kriengsak, T., U. Boonprakob, K. Crosby, L. Zevallos and D.H. Byrne (2006). Comparison of ABTS, DPPH, FRAP, and ORAC assays for estimating. Comp. and Anal., 19: 669-675.

Liong, M.T. and N.P. Shal (2006). Effects of lactobacillus casei synbiotics on serum lipoprotein, intestinal, microflora and organic acid in rats. J. Dairy Sci., 89 : 1390.

Lutterodt, H., M. Slavin, M. Whent, E. Turner, and L. Yu (2011). Fatty acid composition, oxidative stability, antioxidant and ant proliferative properties of selected coldpressed grape seed oils and flours. Food Chem., 128 : 391-399.

Mattila, P., J. Astola and J. Kumpulanien (2000). Determination of flavonoids in plant material by HPLC with diode-array and electro-array detections. J. Agric. Food Chem., 48: 58345841.

Memon, A.A., D.L. MemonLuthria, M.I. Bhanger and A.A. Pitafi (2010). Phenolic acids profiling and antioxidant potential of mulberry (Morus laevigata w., Morus nigra L., Morus alba L.) leaves and fruits grown in pakistan. Pol. J. Food Nutr. Sci., 60 (1): 2532.

Menrad, K. (2003). Market and marketing functional food in europe J. Food Eng., 56: 181-188.
Mensink, R.P. (2005). Effect of stearic acid on plasma lipid and lipoprotein in human. Lipids, $40: 1201$

Mensink, R.P., P.L. Zock, A.D. Kester and M.B. Katen (2003). Effect of dietary fatty acids and carbohydrates on the ratio of serum total and HDL cholesterol and on serum lipid and apolipopteins A, eta-analysis of 60 controlled trials. Ame. J. Clinical Nutr., 77 : 1146.

Mollet, B. and I. Rowland (2002). Functional food. At the trontier between food and pharma. Current Opinion in Biotechnol., 13: 483- 485.

Nahak, G. and R.K. Sahu (2010). Antioxidant activity in bark and roots of Neem (Azadirachta indica) and Mahaneem (Melia azedarach). Cont. J. Pharm. Sci., 4 : 28-34.

Ney, D.M. (1991). Potential for enhancing the nutritional properties of milk fat. J. Dairy Sci., 74 : 4002-4012.

Pawar, N., K. Gandhi, A. Purohit, S. Arora and R.R.B. Singh (2014). Effect of added herb extracts on oxidative stability of (butter oil) during accelerated oxidation condition. J. Food Sci. Technol., 51 (10): 2727-2733.

Peschel, W., F. Sanchez-Rabaneda, W. Diekmann, A. Plescher, I. Gartzia, J. Dimenez, R. Lamuela-Raventos, S. Buxaderas and G. Codina (2006). An industrial approach in the search of natural antioxidants from vegetable and fruit wastes. Food Chem., 97: 137-150.

Prakasha, G.K., R.P. Singh and K.K. Sakariah (2001). Antioxidant activity of grape seeds extracts on peroxidation models in vitro. Food Chem., 73:285-290.

Presa, O.S. and M.C.S. Lopez (1995). Shelf-life prediction of an infant formula using an accelerated stability test (Rancimat). J. Agric. Food Chem., 43: 2879-2882

Ramadan, M.F. (2014). Studies on some dairy products analogues. Ph.D. Thesis, Fac. Agric., Zagazig Univ., Egypt.

Reddy, K.Y. Khetra and M.H.S. Kumar (2016). Fatril dairy products Agri Moon Team. April, 25. 
Rodrigues, J.N. and L.A. Gioielli (2003). Chemical interestrification of milk fat- corn oil blends, Food Res. Int., 36 : 149.

SAS (1998). User's Guide.6.12 and Statistical Analysis System Institute Inc. Cary NC 27511-8000, USA.

Sharma, V. and R. Paliwal (2013). Isolation and characterization of saponins from Moringa oleifera (Moringaeceae) Pods. Int. J. Pharm. Sci., 5 (1): 179-183.

Shehata, A.S. (2005). Studies on Cheese. Ph.D. Thesis, Zagazig Univ., Egypt.

Škerget, M., P. Kotnik, M. Hadolin, A. RižnerHraš, M. Simonič and Z. Knez (2005). Phenols, proanthocyanidins, flavones and flavonols in some plant materials and their antioxidant activities. Food Chem., 89: 191198.

Tao, J., L. Jun, S. Shu-Lan, Z. Zhen-Hua, G. Sheng, Q. Da-Wei and D. Jin-Ao (2016). Identification and determination of the polyhydroxylated alkaloids compounds withglucosidase inhibitor activity in mulberry leaves of different origins. Molec., 21 : 206220.

Tong, L., L. Zhang, S.H. Yu, X.H. Chen and K.S. Bi (2007) .Analysis of the fatty acids from Periploca sepium by GC-MS and GCFID, Asian J. Tradit. Med., 2 : 110-114.

Verma, V.K., N. Singh, P. Saxena and R. Singh (2012). Anti-ulcer and antioxidant activity of Moringa oleifera (Lam) leaves against aspirin and ethanol induced gastric ulcer in rats. Int. Res. J. Pharmaceuticals, 02: 46-57.

Williams, C. (2006). Improving the Fat Contents of Food. Abington Hall, Abington Cambridge UK; Woodhead Pubishing Ltd.

Yang, X.L., L. Yang and H.Y. Zheng (2010). Hypolipidemic and antioxidant effects of mulberry (Morus alba L.) fruit in hyperlipidemia rats. Food Chem. Toxicol., 48: 2374-2379.

Yu, J., M. Ahmedna and I. Goktepe (2005). Effects of processing methods and extraction solvents on concentration and antioxidant activity of peanut skin phenolics. Food Chem., 90: 199-206.

Zaghlool, W.Z., A. Rabie and A.A. Abd ElBaky (2009). An Attempt to produce an acceptable quality ghee like with increased degree of unsaturation. Zagazig J. Agric. Res., 36 (5): 1053 - 1069.

Zaki, D.A., M. Ragab, N.M. Elshafie and F.Z. Mohamed (2014). Phenolic compounds of ethanolic extracts from some food by products. Zagazig J. Agric. Res., 41 (3) : 563- 574.

Zhang, Y., C. Ren, G. Lu, Z. Mu, W. Cui, H. Gao and Y. Wang (2014).Anti-diabetic effect of mulberry leaf polysaccharide by inhibiting pancreatic islet cell apoptosis and ameliorating insulin secretory capacity in diabetic rats. Int. Immunopharmacol, 22 : $248-257$. 


\title{
تأثير بعض مضادات الأكسدة الطبيعية على ثبات أكسدة المنتج الثبيهة بالسمن المحتوى على مستوى الأي

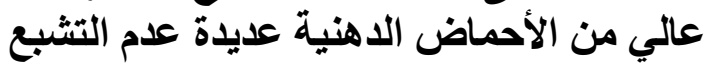

\author{
إسلام عماد الاين دياب ـ صلاح عبدالجليل خليفة ـ السيد حسن عطوة ـ عطية عبدالمعىى عبدالباقى

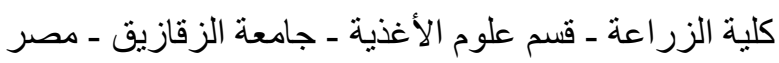

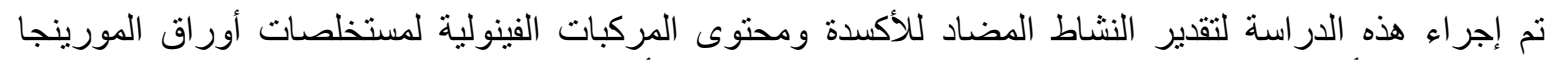

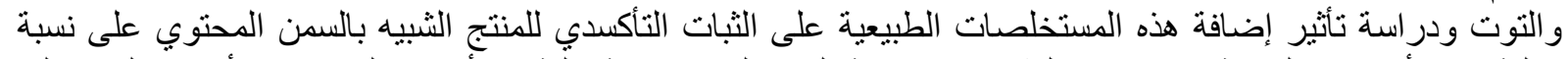

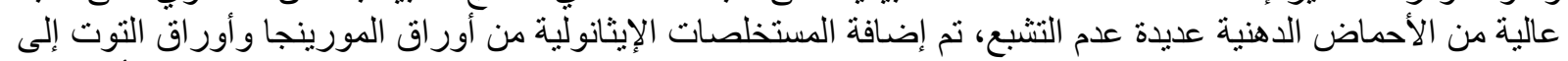

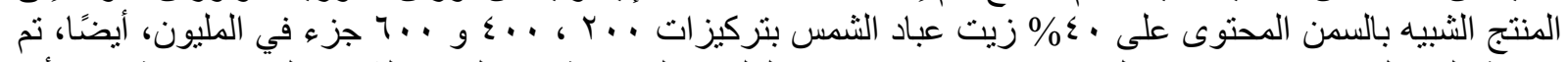

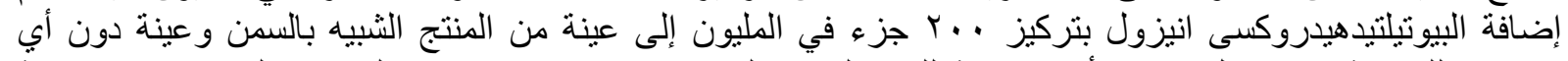

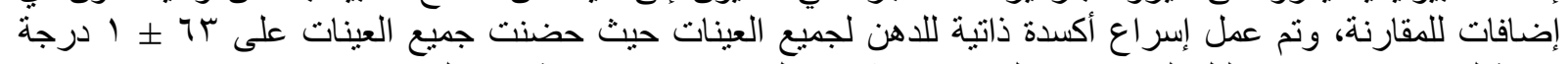

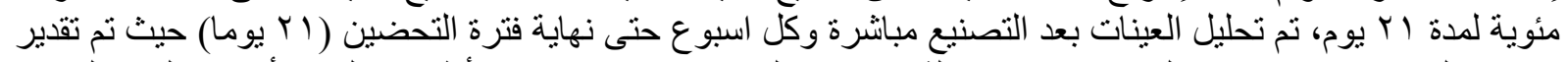

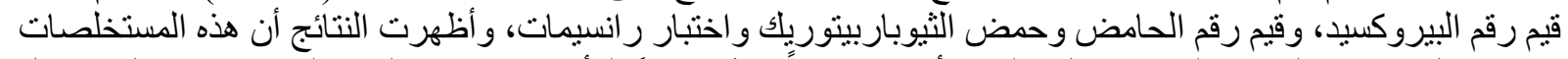

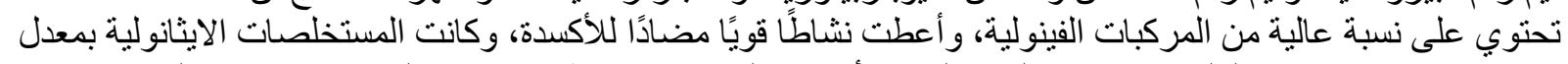

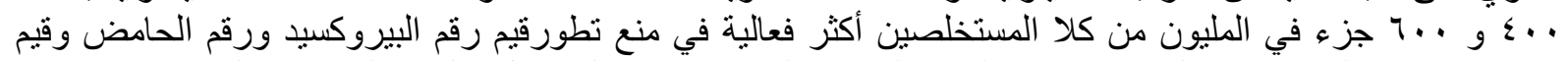

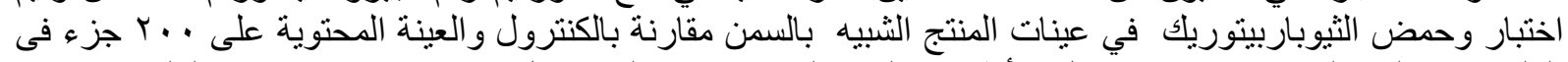

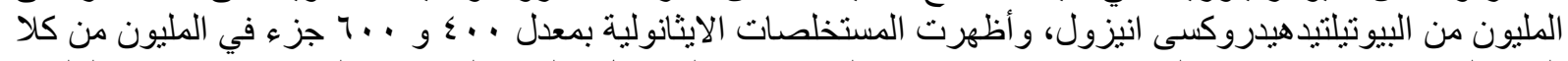

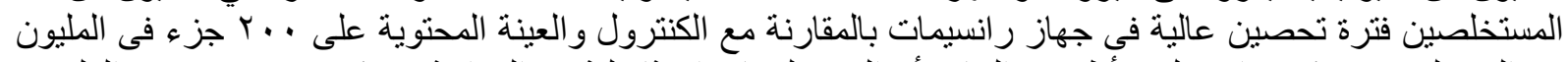

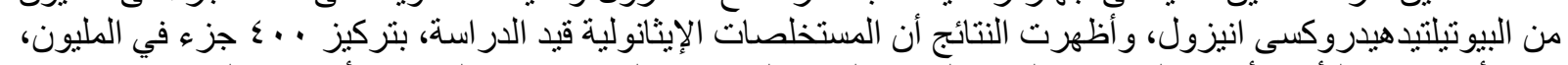

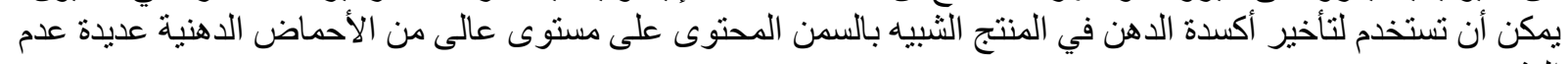
التشبع. 